\title{
The pine shoot beetle Tomicus piniperda as a plausible vector of Fusarium circinatum in northern Spain
}

\author{
Diana Bezos $^{1}$ • Pablo Martínez-Álvarez ${ }^{1} \cdot$ Julio J. Diez $^{1} \cdot$ Mercedes M. Fernández $^{1}$
}

Received: 16 March 2015 / Accepted: 7 August 2015 / Published online: 9 September 2015

(C) INRA and Springer-Verlag France 2015

\begin{abstract}
- Key message The pine shoot beetle, Tomicus piniperda, is a potential vector of the pitch canker disease pathogen. The insect could transmit the pathogenic fungus during its maturation or regeneration feeding on the shoots of healthy pine crowns.

- Context Fusarium circinatum, the causal agent of pitch canker disease, currently affects Pinus radiata in northern Spain, causing pitch-soaked cankers and tree death. Although several species of the family Scolytinae have been reported as vectors of this pathogen, the role of the pine shoot beetle T. piniperda remains unclear.

- Aims The general objective of this study was to determine whether T. piniperda is a vector for the pitch canker pathogen F. circinatum. For this purpose, Leach's postulates (1) an
\end{abstract}

Handling Editor: Aurelien Salle

Contribution of the co-authors Diana Bezos: experimental design, laboratory work, field work, data analysis, writing the paper and manuscript revisions.

Pablo Martínez-Álvarez: field work and manuscript revision.

Julio J. Diez: experimental design, manuscript revision and coordinating the research project.

Mercedes M. Fernández: experimental design, laboratory work, writing the paper, manuscript revision and coordinating the research project.

Diana Bezos

dbezosg@pvs.uva.es

Pablo Martínez-Álvarez

pmtnez@pvs.uva.es

Julio J. Diez

jdcasero@pvs.uva.es

Mercedes M. Fernández

mffernan@agro.uva.es

1 Sustainable Forest Management Research Institute, University of Valladolid-INIA, Madrid Avenue 44, 34004 Palencia, Spain association between $T$. piniperda and trees affected by pitch canker disease; (2) regular visits by $T$. piniperda to healthy $P$. radiata trees; (3) presence of the pathogen on the insect in nature; and (4) transmission of the pathogen to disease-free host material under controlled conditions.

- Methods Fresh green shoots with feeding galleries were collected from the ground, breeding galleries were collected from diseased trunks and insects were collected during their dispersion flights. A laboratory experiment was conducted in which specimens of $T$. piniperda were inoculated with the pathogen prior to feeding on shoots.

- Results In the field, T. piniperda was found to be associated with both diseased and healthy $P$. radiata trees, and $F$. circinatum was found to be present, at low rates, on the exoskeleton of $T$. piniperda. In the laboratory experiment, evidence of the ability of $T$. piniperda to transfer the pathogen to healthy shoots was found.

- Conclusions The study findings indicate T. piniperda as a plausible vector of this pathogen. We postulate for the first time a potential relationship between the life cycles of T. piniperda and F. circinatum.

Keywords Pitch canker - Pinus radiata P Pine shoot beetle . Forest disease

\section{Introduction}

Fusarium circinatum Nirenberg and O'Donnell is an ascomycete fungus that causes pitch canker disease (PCD) in pines (Nirenberg and O'Donnell 1998). The disease is characterised by the formation of large deformed resin-filled cankers, which affect both the trunk and thick branches. The pathogen threatens Pinus radiata D. Don plantations and natural forests throughout the world (Martínez-Álvarez et al. 2014 and 
references there in), because of the high susceptibility of this pine species (Viljoen et al. 1995). In Spain, F. circinatum was first reported in 2005 (Landeras et al. 2005), although it is suspected that the pathogen has been causing damage since 1997 (Laucirica and Muguruza 1997).

F. circinatum spores may be dispersed by wind, water and seedling transport as well as by the activity of insects while excavating their breeding galleries or feeding on the crowns of healthy trees (Storer et al. 2004). Some insects like Pityophthorus carmeli Swaine are vectors of the disease in California (Storer et al. 2004), while in the Iberian Peninsula, several species of beetles, such as Pityophthorus pubescens (Marsham), Hylurgops palliatus (Gyllenhal), Ips sexdentatus (Börner), Hypothenemus eruditus (Westwood), Hylastes attenuatus (Erichson) and Orthotomicus erosus (Wollaston), are known to be phoretically associated with the pathogen (Romón et al. 2007a). The widely studied complex interaction between fungal pathogens and insects is typically considered as a mutual relationship between the vector and the fungus with ecological advantages for both organisms (Paine et al. 1997). For instance, some pathogenic fungi, specially blue stain fungi, by stimulating tree defence mechanism, could contribute to tree resistance exhaustion and consequently enable beetle and fungi establishment in host tissue (Lieutier et al. 2009). However, as it has been demonstrated that bark beetles can kill trees when no pathogenic fungi are present, other authors have suggested that in this association, the fungal pathogenicity may only benefit the fungus rather than the beetle (Six and Wingfield 2011).

Tomicus piniperda L. (Coleoptera; Scolytinae) is a serious pest that affects pines in Europe, Northern Africa, Asia (Långström 1982; Bouhot et al. 1988; Kirkendall et al. 2008) and the USA (McCullough and Smitley 1995). Although the main host is Pinus sylvestris L., other pine species are also suitable as hosts, e.g. $P$. radiata. T. piniperda is a univoltine species that may produce several sister broods. The species is considered a secondary pest colonizing trunks and thick branches of weakened trees (Paine et al. 1997). However, emerging young adults, as other Tomicus species, perform a maturation feeding on shoots and can act then as a primary species (Långström 1982; Fernández et al. 1999; Gallego et al. 2008; Lieutier et al. 2015). Each insect penetrates more than one shoot during the feeding phase, especially in the thicker and fresh current-year shoots (Tiberi et al. 2009). They can negatively affect tree growth and structure of healthy trees, cause carbon and nitrogen losses and, in cases of high population densities, death of the tree (López et al. 2007). The fact that T. piniperda weakens the host tree after feeding on shoots also increases the number of reproductive niches susceptible to colonization, although shoot damage by T. piniperda rarely exceeds 50 \% (Långström 1980).
Because of this maturation feeding on the crowns of healthy pines, $T$. piniperda is a strong candidate as an effective vector of $F$. circinatum in the study area. In addition, in southern Europe, T. piniperda overwinters within the shoots (Russo 1946). Thus, in the study area, the beetle can remain for 6 to 9 months within the shoots. The possibility that this species is a vector of the fungus is further supported by the fact that the main symptom associated with the presence of $F$. circinatum in shoots excavated by the insects is severe necrosis of the pith (Fig. 1). However, little is known about the effectiveness and importance of the life cycle of Tomicus species regarding transmission of the pathogen. T. piniperda is associated with virulent ophiostomatoid fungi, such as Leptographium wingfieldii Morelet in Europe (Lieutier et al. 1989; Jacobs et al. 2004) and Ophiostoma minus (Hedgc.) Syd. \& P. Syd. (Solheim et al. 2001; Jankowiak and Bilański 2007).

The general objective of this study was to determine whether the pine shoot beetle T. piniperda is a vector for the pitch canker pathogen $F$. circinatum. For this purpose, Leach's postulates (Leach 1940) were tested: (1) a close, although not necessarily constant, association between $T$. piniperda and trees affected by pitch canker disease; (2) regular visits by $T$. piniperda to healthy $P$. radiata trees; (3) the presence of the pathogen on the insect in nature; and (4) whether T. piniperda can successfully transmit the pathogen to disease-free host material under controlled conditions.

\section{Materials and methods}

Different methods were applied with the aim of testing Leach's postulates. To establish an association between

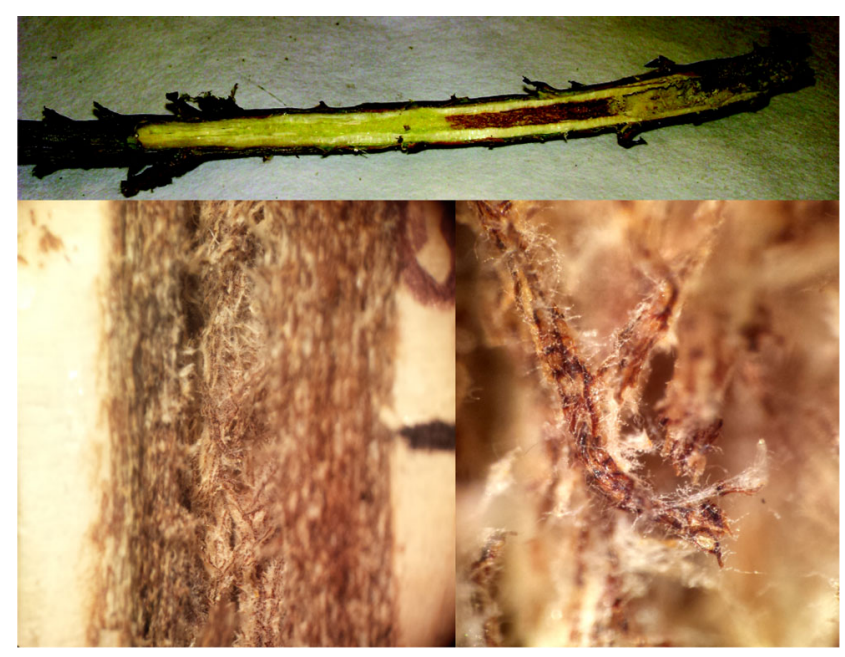

Fig. 1 a Pinus radiata shoot with Tomicus piniperda feeding gallery, necrotic pith and green tissue, $\mathbf{b}$ and $\mathbf{c}$ details of $F$. circinatum structures growing on the necrotic pith 
T. piniperda and diseased trees (postulate 1), samples were collected from breeding galleries on trees affected by F. circinatum for examination. To determine whether T. piniperda regularly visits healthy pines (postulate 2 ), fresh green shoots of $P$. radiata bored by the insect were collected from the ground and analysed for the presence of the pathogen. To determine whether the pathogen occurs on the insects in nature (postulate 3), funnel traps were placed in a plot affected by pitch canker. Finally, the symptoms of the disease were produced experimentally under controlled conditions (postulate 4) on healthy shoots on which artificially inoculated specimens of $T$. piniperda were fed.

Molecular identification of insects was carried out, because of the possible sympatry between T. piniperda and Tomicus destruens in the study area (Gallego et al. 2004) and because of the complexity of identifying some morphological characters or even their absence in some individuals (Faccoli 2006). For this purpose, the DNA was extracted from nine randomly selected insects, with the Biotools extraction kit (Speedtools Tissue DNA Extraction Kit). Samples were taken from the insects' heads to prevent contamination due to fungi and nematodes present in the digestive tract and elytra. The ITS2 fragment was amplified by PCR with the ITS3 (5.8S region) and ITS4 primers (28S region). PCR was performed in a reaction volume of $25 \mu \mathrm{l}$, and the cycling programme was $5 \mathrm{~min}$ at $96{ }^{\circ} \mathrm{C}$ followed by 35 cycles of $30 \mathrm{~s}$ at $96^{\circ} \mathrm{C}, 1 \mathrm{~min}$ at $50^{\circ} \mathrm{C}$ and $1 \mathrm{~min}$ at $72{ }^{\circ} \mathrm{C}$ with a final elongation $10 \mathrm{~min}$ at $72{ }^{\circ} \mathrm{C}$. The PCR product was purified and digested with Hinc II restriction enzyme overnight at $37{ }^{\circ} \mathrm{C}$. The digestion product was observed by agarose gel electrophoresis (MetaPhor) (Gallego and Galian 2001).

\subsection{Association between T. piniperda and diseased trees}

With the aim of studying the association between T. piniperda and diseased trees, breeding galleries were collected from a $P$. radiata plot affected by PCD in Santibañez (Cabezón de la Sal, Cantabria) (Martínez-Álvarez et al. 2012). Ten trees with pitch cankers on the trunks were sampled in 2014. Tree bark showing signs of the presence of T. piniperda next to the cankers was removed, with an axe, and analysed in the laboratory along with plant tissue collected from breeding galleries. The gallery tissue was plated on potato dextrose agar (PDA, Scharlau) modified by the addition of $0.6 \mathrm{~g}$ of streptomycin sulphate (Fluka Analytical) per $39 \mathrm{~g}$ of PDA (PDAS), after superficial sterilization of the samples by submergence in $100 \mathrm{ml}$ each of four different liquids ( $1 \mathrm{~min}$ tap water, $1 \mathrm{~min}$ $70 \%$ ethanol, $1 \mathrm{~min}$ sodium hypochlorite $2 \%, 1 \mathrm{~min}$ sterile distilled water). The material from five of the breeding galleries from which $F$. circinatum had been isolated by plating on PDAS was placed on wet chambers for microscopic observation of the structure of the pathogen. With the aim of determining whether $F$. circinatum was present on breeding specimens of $T$. piniperda on diseased trunks, insects at different developmental stages were collected from galleries (15 parental adults, $32 \mathrm{~F} 1$ adults, 23 pupae and 58 larvae). The insect material was then plated on PDAS media in accordance with the methodology described by Ambourn et al. (2006) with some modifications; each insect was placed in a $1.5-\mathrm{ml}$ microtube with $200 \mu \mathrm{l}$ of $1 \%$ Tween 80 and sonicated for $5 \mathrm{~s}$. One hundred microlitres of the solution was plated on PDAS and extended on the medium with a sterile loop. F. circinatum colonies were identified by their morphology following the method described by Leslie and Summerell (2006) for culturing mycelia on synthetischer nährstoffärmer agar (SNA). The typical structures of this fungus (i.e. oval microconidia, mono and polyphialides, coiled sterile hyphae and absence of clamidiospores) were observed on SNA. The differences between the different insect stages collected from the breeding galleries in relation to presence of $F$. circinatum were analysed by Fisher's exact test (SPSS software).

\subsection{Association between T. piniperda and healthy trees}

The association between $T$. piniperda and healthy crowns of pine trees has been studied by different authors (Långström 1982; Lieutier et al. 2015). In the present study, we aimed to demonstrate the capacity of $T$. piniperda to infest symptomfree green crowns of $P$. radiata trees in plots affected by pitch canker. Between April 2011 and June 2012, 954 fresh green fallen shoots bored by $T$. piniperda were collected in six $P$. radiata plots affected by $F$. circinatum in Cantabria (Cabezon de la Sal, Udías, Rionansa and Santiurde de Toranzo) (Martínez-Álvarez et al. 2012). Sampling was carried out for $1 \mathrm{~h}$ every 15 days, and up to 100 shoots were collected monthly. As the length of the feeding gallery may be related to the time that the insect spends within the shoot, the presence of $F$. circinatum may be influenced by the gallery length, which was therefore measured in each shoot. The section of each shoot burrowed by the insect was plated on PDAS medium, after surface sterilization of the sample by submergence in $100 \mathrm{ml}$ of four different solutions (1 min tap water, $1 \mathrm{~min} 70 \%$ ethanol, 1 min sodium hypochlorite $2 \%, 1 \mathrm{~min}$ sterile distilled water). To establish any possible influence of the season on the presence of the pathogen inside the shoot galleries, a chi-square test was conducted. To analyse the influence of the gallery length on the presence of the pathogen, a logistic regression was carried out.

To identify the part of the shoots where the pathogen was most abundant, and to determine the development of the pathogen within the shoot, three different areas were identified (gallery, necrotic pith and transition zone) (Fig. 1). The tissue collected from each area was subsequently plated on PDAS. This analysis was carried out with the 200 fallen shoots infested with $T$. piniperda that were collected during January and February 2012. The part of the shoot where the insect 
bores to make its feeding gallery was considered as the "gallery"; the adjacent part with brown pith was considered the "necrotic pith"; and the part of the shoot where the pith is still green and healthy was classified as the "transition zone". A total of 482 gallery samples, 248 necrotic pith and 65 transition zone samples were analysed. A chi-square test was carried out to evaluate the differences in the number of positive F. circinatum samples found in the gallery relative to the necrotic pith, since the transition zone did not contain a sufficient number of positive isolates for inclusion in the analysis.

To detect the presence of the pathogen on the insects' exoskeletons, 44 specimens found inside the shoot galleries were processed according to the method described above.

\subsection{Presence of $F$. circinatum on $T$. piniperda in nature}

In the periods comprising May-October 2012, February-September 2013 and May-August 2014, two sliding funnel traps (Econex) were baited with ethanol and $\alpha$-pinene (Econex) in a plot affected by F. circinatum (Cabezón de la Sal, Cantabria). Captured specimens were collected weekly. In order to avoid catching beetle predators, mesh grids $(5 \mathrm{~mm})$ were placed over the funnels (Martín et al. 2013). To determine the presence of spores attached to the body of $T$. piniperda, the specimens were cultured on PDAS as described above. In addition, between February and September 2013, two additional sliding traps were baited with ethanol and $\alpha$-pinene and placed in a disease-free plot of P. sylvestris located in San Miguel de Aguayo (Cantabria).

\subsection{Transmission assay under controlled conditions}

In March 2012, ten logs of $P$. sylvestris naturally attacked by T. piniperda and free of $F$. circinatum were collected in San Miguel de Aguayo (Cantabria). The logs $(50 \mathrm{~cm}$ in length and $15 \mathrm{~cm}$ in diameter) were placed in emergence boxes in the laboratory to collect both reemerging parental and emerging F1 progeny. In order to confirm that the insects obtained from $\operatorname{logs}$ collected in the field were free of $F$. circinatum, reemerging parents ( 25 females and 40 males) and 50 young specimens ( 25 males and 25 females) that emerged from the $P$. sylvestris $\log$ sere analysed for the presence of F. circinatum, as described above.

The F1 insects emerging from the logs were experimentally infected with $F$. circinatum for subsequent testing of the insect's ability to infect healthy $P$. radiata shoots. Thus, the insects were allowed to walk for different durations $(1,10$, 30 and $60 \mathrm{~min}$ ) on PDAS plates completely covered by $F$. circinatum mycelium. The four shoot + insect + mycelium (SIM) treatments tested were designated $\mathrm{SIMa}=1^{\prime}, \mathrm{SIMb}=$ $10^{\prime}, \mathrm{SIMc}=30^{\prime}$ and SIMd $=60^{\prime}$. For these treatments, each insect was placed in a sterile glass jar $(20.5 \mathrm{~cm}$ in high and $11 \mathrm{~cm}$ in diameter) with a current fresh $F$. circinatum-free shoot, of length $20 \mathrm{~cm}$, to enable it to carry out its maturation feeding and infect the shoot with the pathogen. Twenty insects and 20 shoots were used for each treatment (Table 1). Prior to this experiment, a test was conducted to determine the optimal number of days required for the fungus to develop inside the shoots in which the insect had burrowed, by leaving the insects and shoots in the jars for 5, 10 and 20 days. The results confirmed that 10 days was the optimum length of time for the insect to carry out maturation feeding and to transfer the pathogen without growth of saprophytic fungi.

Positive controls without insects, shoot + mycelium (SMC), were prepared by boring the shoots with a 5 -mm cork-borer and placing an agar disc with the pathogen in direct contact with the pith. Finally, a control treatment, shoot + insect (SIC), was established by placing $F$. circinatum-free insects in individual jars to feed on healthy shoots. Ten days after the beginning of each treatment, the length of the feeding gallery made by the insect and the length of the necrosis caused by the pathogen in the pith was recorded in each shoot. In the SMC treatment, the length of the necrotic pith was also measured. At the end of the trial, $25 \%$ of the shoots ( 5 shoots per treatment, 30 in total) were randomly selected for plating on PDAS, after superficial sterilization of the material, in order to isolate the pathogen. The above-described method was used to process $25 \%$ of the insects.

Data from the inoculation assay were analysed by a oneway ANOVA to test the influence of the treatment on the gallery length and on the necrosis length, followed by a post hoc analysis (Tukey's test).

All statistical analyses were carried out with SPSS software.

To confirm the effectiveness of the method of infecting the insects with the fungus, 40 young specimens of $T$. piniperda from the F1 generation (10 insects per treatment) were infected via contact with mycelium for four different mycelium + insect (MI): $\mathrm{MIa}=1^{\prime}, \mathrm{MIb}=10^{\prime}, \mathrm{MIc}=30^{\prime}$ and $\mathrm{MId}=60^{\prime}$ and

Table 1 Different experimental infection treatments with insects and/or shoots

\begin{tabular}{lll}
\hline Name & Materials & $N$ \\
\hline SIMa & Shoot+insect+mycelium 1 min & 20 \\
SIMb & Shoot+insect+mycelium 10 min & 20 \\
SIMc & Shoot+insect+30 min & 20 \\
SIMd & Shoot+insect+mycelium 60 min & 20 \\
SIC & Shoot+insect=control & 20 \\
MIa & Insect+mycelium 1 min & 10 \\
MIb & Insect+mycelium 10 min & 10 \\
MIc & Insect+mycelium 30 min & 10 \\
MId & Insect+mycelium 60 min & 10 \\
SMC & Shoot+mycelium (5 mm ø)=positive control & 20 \\
\hline
\end{tabular}


the processed samples were subsequently plated on Fusarium selective medium (FSM).

F. circinatum colonies were identified morphologically by culture on SNA medium.

Moreover, to determine where the pathogen is harboured by the insect, 20 specimens of $T$. piniperda were inoculated. For this purpose, the insects walked on a plate with mycelium for two different durations (treatments: $A=1 \mathrm{~min}, B=10 \mathrm{~min}$ ). The insect samples were then frozen at $-20^{\circ} \mathrm{C}$ and sent to the National Research Center on Human Evolution (Burgos, Spain) for processing by scanning electron microscopy to identify the most common sites of adhesion of the spores to the insect exoskeleton. The insect samples were coated with gold film $(10 \mathrm{~nm})$ and examined in a FEI Quanta 650 scanning electron microscope.

\section{Results}

The insect specimens were identified as $T$. piniperda by detection of the restriction pattern of the ITS2 region after enzymatic digestion with HincII, i.e. two bands of around 221 and 339 bp (Gallego and Galian 2001).

\subsection{Association between $T$. piniperda and diseased trees}

In 2014, a total of 118 beetle specimens were collected between May and July from 10 trees with symptoms of PCD. $F$. circinatum was isolated at all the development stages although the differences between stages were not statistically significant: $33 \%$ of the parental adults, $15 \%$ of the F1 adults, $13 \%$ of the pupae and $15 \%$ of the larvae. A total of 121 breeding galleries were sampled in 2014 from symptomatic trees, and $16 \%$ of them gave rise to $F$. circinatum colonies when plated on PDAs. The F. circinatum structures were observed on all samples placed in wet chambers.

\subsection{Association between $T$. piniperda and healthy trees}

F. circinatum was isolated from $12 \%$ of the 571 shoots collected from the ground between April and December 2011. No F. circinatum-infected shoots were found in May or June, whereas maximum numbers were reached in November and December (21 and $29 \%$, respectively). Regarding the 383 shoots collected between January and June 2012, 10 \% were positive for $F$. circinatum, with maximum values for the months of January and February (26 and $8 \%$, respectively), whereas no positive shoots were observed in May and June (Fig. 2). The presence of $F$. circinatum was not significantly affected by season in which they were collected $\left(\mathrm{df}=3, X^{2}=\right.$ 46.389, $p=0.059$ ), although most specimens were found in winter (64 out of 236, $27 \%$ ) followed by autumn (16 out of $236,7 \%$ ) and spring (6 out of $74,3 \%$ ). The presence of
F. circinatum was not significantly influenced by the length of gallery length excavated by the insects $(\mathrm{df}=1, F=3.579, p=$ 0.059 ). The mean length of the gallery was longer in shoots in which $F$. circinatum was detected $(2.4 \mathrm{~cm})$ than in shoots that tested negative for the pathogen $(2 \mathrm{~cm})$.

In the three different areas of the 200 shoots analysed (484 gallery samples, 244 necrotic pith samples and 65 transition zone samples), $10 \%$ of the galleries, $5 \%$ of the cultivated necrotic pith and $1 \%$ of the transition zones were positive for $F$. circinatum. The rate of infection was significantly different in the gallery and the necrotic pith $\left(\mathrm{df}=1, X^{2}=5.361\right.$, $p=0.021$ ).

During the entire sampling period, a total of 44 insects were found inside the shoot feeding galleries. F. circinatum was isolated from one specimen collected in November. During the winter period, the occupation rate $(\%$ of shoots occupied by an insect) of the galleries was $5 \%$, while in the summer, it was $2 \%$, in the spring, $5 \%$, and in autumn, $6 \%$.

\subsection{Presence of $F$. circinatum on $T$. piniperda in nature}

The total numbers of individual $T$. piniperda collected from funnel traps were 6, 74 and 3 in, respectively, 2012, 2013 and 2014. Of the 74 specimens collected in 2013, $69 \%$ were captured in March, $23 \%$ in April, $8 \%$ in May and $0 \%$ in June. F. circinatum was isolated from 2 of the insects captured in 2012, in May and August, and from 1 of those collected in May 2014. F. circinatum was not isolated from any of the specimens captured in 2013. In the funnel traps placed in a P. sylvestris plot free of the disease in 2013, a total of 65 beetles were collected: $5 \%$ in March, $90 \%$ in April, $5 \%$ in May and $0 \%$ in June. None of these specimens carried the pathogen.

\subsection{Transmission assay under controlled conditions}

All re-emerged parents and offspring obtained from the $P$. sylvestris logs from San Miguel de Aguayo were free of $F$. circinatum. The rate of reisolation of $F$. circinatum from inoculated shoots and insects varied depending on the treatment. In the plant tissue in treatments SIMa, SIMb, SIMc and SIMd, F. circinatum was found in 60, 60, 40 and $20 \%$ of the shoots, respectively, whereas in the SM treatment, it was present in $100 \%$ of the shoots. The pathogen was reisolated in 60 , 60,40 and $40 \%$ of the inoculated insects feeding on shoots in treatments SIMa, SIMb, SIMc and SIMd, respectively. However, the rate of reisolation was higher in the four treatments MIa, MIb, MIc and MId (80, 90, 60 and $60 \%$, respectively).

In the inoculation assay, there were no significant differences between the treatments (SIMa, SIMb, SIMc, SIMd and $\mathrm{SIC})$ in relation to gallery length $(\mathrm{df}=4, F=1.133, p=0.347)$ (Fig. 3). However, there were significant differences between SIM treatments (SIMa, SIMb, SIMc and SIMd) and SM, but 
Fig. 2 Percentage of Pinus radiata shoots collected in the field from which Fusarium circinatum was isolated at each sampling period

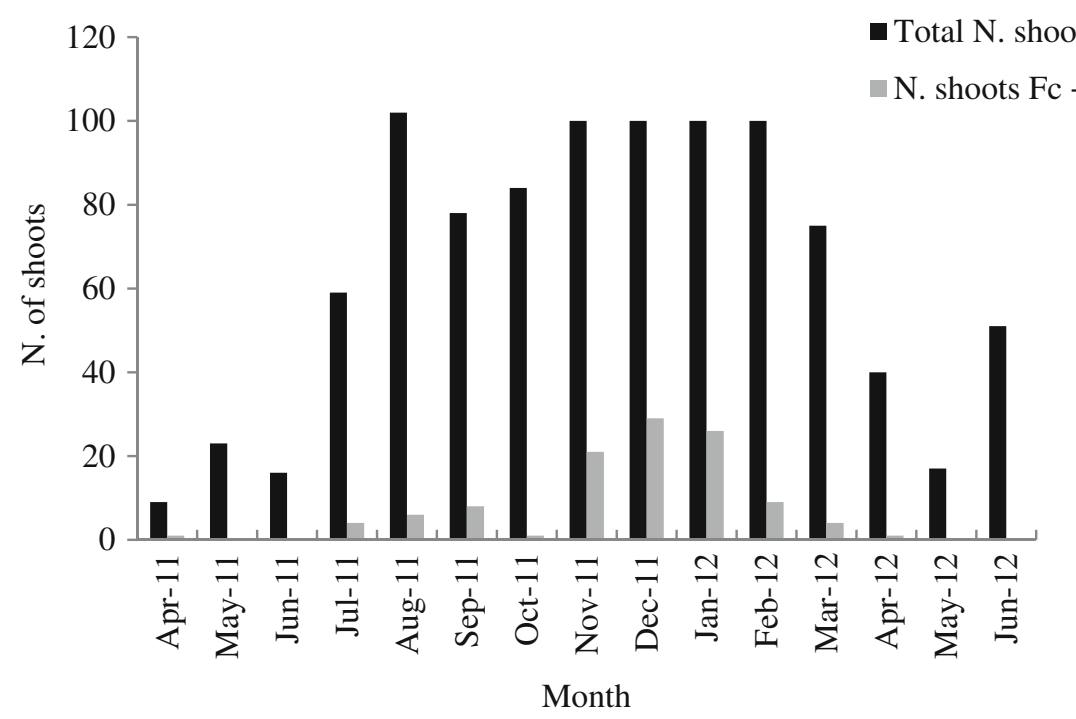

not among SIMa, SIMb, SIMc and SIMd treatments in relation to the length of the necrotic area (Fig. 3).

The electron micrographs revealed the presence of $F$. circinatum structures on the insects' bodies in both inoculation treatments $(A=1 \mathrm{~min}$ and $B=10 \mathrm{~min})$. Microconidia and phialides were clearly observed (Figs. 4 and 5, respectively).

\section{Discussion}

This study aimed to confirm whether $T$. piniperda is a likely vector of $F$. circinatum in $P$. radiata plantations in northern Spain, on the basis of Leach's postulates (Leach 1940). The hypothesis was confirmed by the following observations: an association between the insect and trees affected by pitch canker disease (postulate 1); an association between the insect

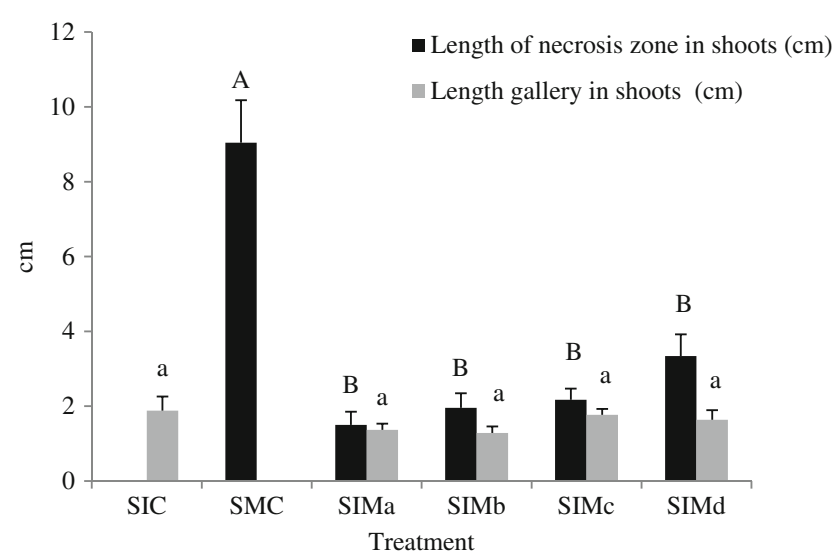

Fig. 3 Mean length of necrotic zone and mean length of the gallery by the insects in the shoots in the experimental infection assay. Different letters represent significant differences (capital letters indicate length of necrotic zone and lower case letters indicate gallery length). Error bars represent standard error and healthy $P$. radiata trees (postulate 2); the presence of the pathogen on the exoskeleton of $T$. piniperda specimens in nature (postulate 3 ); and the capacity of $T$. piniperda to transmit the disease to healthy host material under certain controlled conditions (postulate 4).

The association between $T$. piniperda and $P$. radiata trees affected by pitch canker disease was observed during field sampling in 2014. Breeding galleries (and the insects they contained) collected from symptomatic trees were positive for $F$. circinatum. This may indicate that the insect was already infected with the pathogen when excavating the breeding gallery or that the bark where the insects made the galleries was already infected with $F$. circinatum. The probability of $T$. piniperda being contaminated with the pathogen would be increased by the insects excavating their breeding galleries in diseased trees. Microscopic examination of samples in

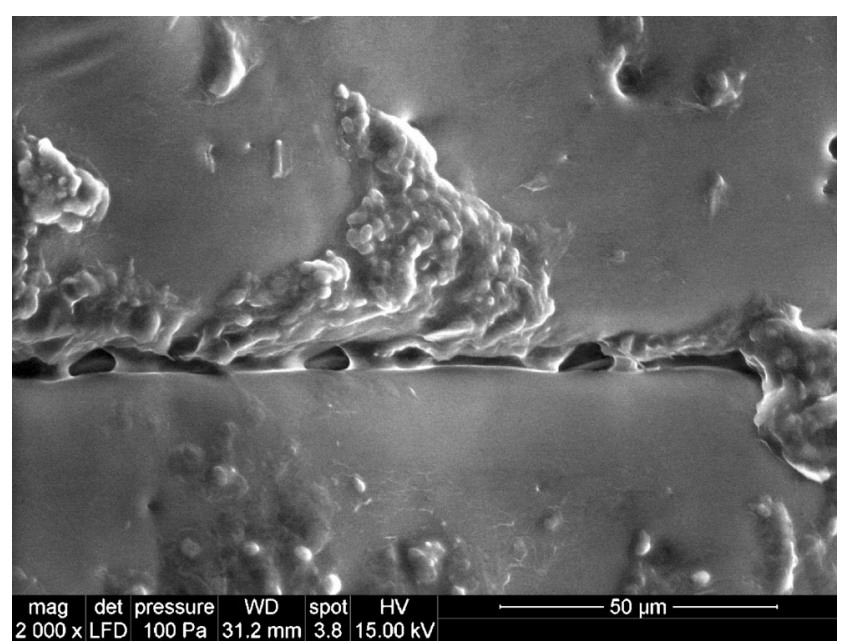

Fig. 4 Tomicus piniperda elytra with microconidia of Fusarium circinatum 


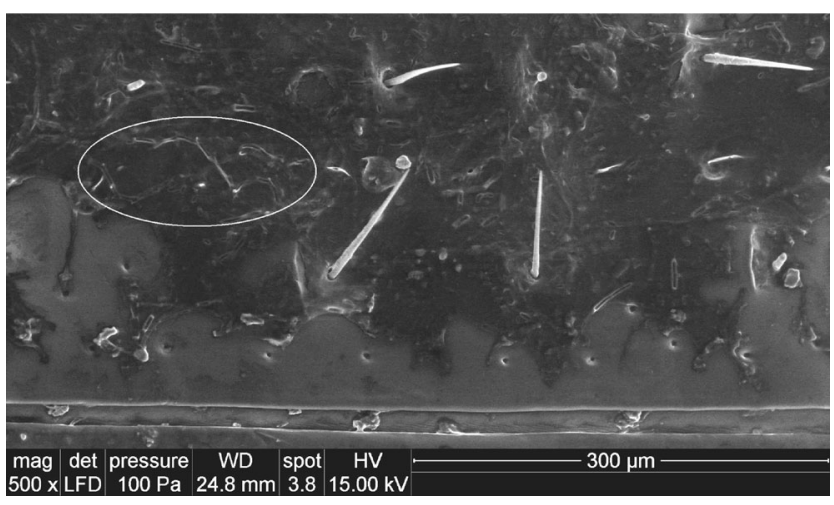

Fig. 5 Tomicus piniperda elytra with phialides of Fusarium circinatum

wet chambers revealed $F$. circinatum structures growing in the breeding galleries, suggesting that breeding galleries provide suitable conditions for fungal fruiting.

Regarding the second postulate, the association between T. piniperda and healthy crowns of pine trees has been intensively studied by several authors (Långström 1982; Lieutier et al. 2015). In this study, $11 \%$ of the 957 fresh shoots collected from green crowns were positive for F. circinatum, and the fungus appeared in a higher proportion inside the feeding galleries than in the surrounding areas. This may indicate the role of $T$. piniperda as a wounding agent, as $F$. circinatum requires a wound to penetrate and infect the tree (Dwinell et al. 1985). However, the finding may also indicate that T. piniperda infects the shoots with the pathogen during feeding on shoots. The fact that $T$. piniperd $a$ attacks symptomless green crowns in plots affected by pitch canker may increase the incidence of the disease.

The season in which the samples were collected did not affect the presence of $F$. circinatum inside $T$. piniperda feeding galleries on fresh green shoots, although November, December and January were the months with more isolation rates. Gallery length did not significantly influence the presence of the pathogen, although it is related to the time that the insect spends inside the shoot. This sampling was carried out as a first approach to determine the factors influencing the distribution of $F$. circinatum on the feeding galleries of $T$. piniperda on healthy crowns.

The presence of the pathogen on the insect in nature was tested by collecting insects during their dispersion flight in plots affected by PCD. The T. piniperda population was found to carry an inoculum of $F$. circinatum during its dispersion flight. The observed phoresy rates obtained in this work, i.e. $4 \%$ in 3 years, are consistent with those determined by Whitehill et al. (2007) in a study of the role of Ips pini as a vector of Sphaeropsis sapinea. However, it is low in comparison with the rates observed in other bark beetle-pathogenic fungi systems, e.g. in a study carried out in California, $17 \%$ of Pityophthorus spp. were found to be carrying $F$. circinatum (McNee et al. 2002), and I. sexdentatus was associated with
Ophiostoma ips in Romón et al. (2007b). T. piniperda is known to be associated with other species of pathogenic fungi worldwide (Jacobs et al. 2004; Kirisits 2004), e.g. O. minus, which appears at a very low and variable frequency. Lieutier et al. (2009) described this bark beetle as being capable of exhausting tree defences but very loosely associated with fungi.

In this study, we demonstrated the ability of the insect to infect the shoots with the pathogen during shoot maturation feeding under certain conditions. The presence of the pathogen was confirmed in a high percentage of the shoots from the mycelium inoculation assay (SIMa $=60 \%, \operatorname{SIMb}=60 \%$, $\mathrm{SIMc}=40 \%$ and SIMd $=20 \%$ ). These results are not consistent with those obtained during the field sampling. This may be related to the method of inoculation, highlighting the need to determine how the insect is loaded with $F$. circinatum spores in nature. The insect may become contaminated with spores from zones of the tree where the humidity and temperature conditions are suitable for the mycelium and conidiophores, although it is not known how many spores are harboured on the insect exoskeleton. The low phoresy rates observed in the field sampling relative to the experimentally established rates may be explained by the fact that insect flight did not take place in the laboratory experiment. In the laboratory study, the length of time that the insect was in contact with the mycelium did not influence either the length of necrosis on the shoot or the gallery length.

The scanning electron micrographs showed microconidia on the elytra (Fig. 4), whereas the absence of macroconidia was due to the inoculation methodology, as these spores do not grow easily on PDA. Moreover, other F. circinatum structures were observed on the insects' exoskeletons, such as the phialides, the structures that produce microconidia (Fig. 5). Although T. piniperda does not have specific structures for transporting fungus like mycangia (Paine et al. 1997), the spores may be stored in other body locations, as in other bark beetles. For example, Hypothenemus hampei transports $\mathrm{Fu}$ sarium solani spores at the base of its asperites (MoralesRamos et al. 2000). No regular distribution pattern of F. circinatum spores on the T. piniperda exoskeleton was observed. This may be due to the fact that insects were artificially inoculated, what could have condition the distribution of the fungi on the beetle. Moreover, in this inoculation assay, insects did not take flight before feeding on the shoot (or before SEM). In nature, maturation flight may change the distribution pattern of the spores on the insects' exoskeletons, or even lead to loss of spores, before reaching the shoots.

Previous studies have reported the presence of several bark beetle species in plots affected by pitch canker, e.g. I. sexdentatus, $O$. erosus, $P$. pubescens, $H$. palliatus and H. attenuatus (Romón et al. 2008; Bezos et al. 2013). The fact that $T$. piniperda performs its maturation feeding on healthy shoots (Långström 1982) may be critical for the success of this 
insect species as a potentially important vector of this disease compared with other secondary bark beetle species reported in northern Spain as insect vectors of $F$. circinatum (Romón et al. 2007a). Bark beetle species such as I. sexdentatus and $P$. pubescens are phoretically associated with $F$. circinatum according to these authors; however, they do not attack healthy trees at endemic state.

The behaviour of $T$. piniperda throughout its life cycle may enable dispersion of F. circinatum (Fig. 6). The tree that the insects colonise for breeding may be affected by pitch canker and consequently be loaded with the fungal spores or mycelium growing under the bark of the diseased tree, in the same way as occurs with Dutch elm disease (Webber 2008). After the breeding period, both reemerging parents $(\mathrm{P})$ and the young emerging adults (F1) fly to the crowns of healthy pines for regeneration and maturation feeding, respectively. The insects would thus transfer the fungus to healthy current shoots, enabling it to grow inside the feeding gallery and along the pith. As the insects feed on several shoots (Kirkendall et al. 2008), they can thus spread the disease along the tree crown. Moreover, the conditions inside the shoot may be suitable for growth of the pathogen, which may then reinfect the insects before they leave to feed on another healthy shoot. After the maturation feeding, the F1 individuals overwinter inside the shoots while the fungal structures are growing inside the gallery. After regeneration feeding, the reemerging parents fly to new sister brood establishments and can disperse the fungus to other non-affected trees and return to the crowns of healthy trees for regeneration feeding once again. This is supported by the fact that reemerging parents were found inside the feeding shoots during March, April and May (in 2011 and 2012).

The study findings indicate that $T$. piniperda is probably a vector of $F$. circinatum, according to Leach's postulates (Leach 1940). The presence of $F$. circinatum in the galleries and on the bodies of the insects throughout the lifecycle shows that $T$. piniperda may transport the pathogen and later introduce it into healthy trees, under the bark and inside the shoots. The shoots are most likely to become infected with the pathogen during maturation feeding and overwintering. Here, we describe, for the first time, the cycle relating F. circinatum and T. piniperda; however, further studies are required for a better understanding of the relationship between the life cycles of the insect and the pathogen.

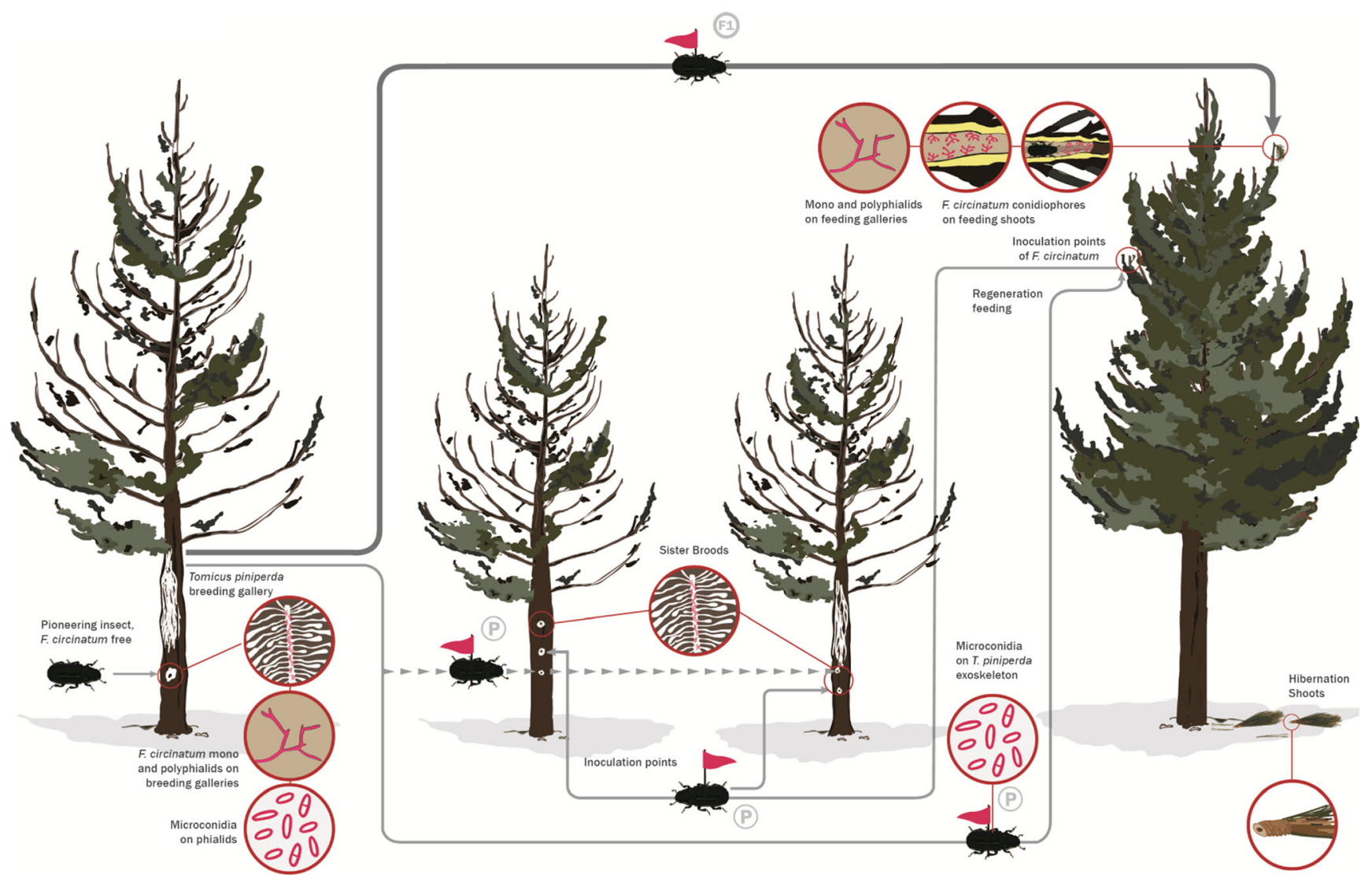

Fig. 6 Dispersion of pitch canker disease during the Tomicus piniperda life cycle. Flags indicate individuals that are conceivably carrying Fusarium circinatum spores. $P$ parental adults, $F 1$ young adults. Thick dark grey line F1 maturation flight; thin light grey line P regeneration flight to crowns, followed by dispersion flight; dashed light grey line $\mathrm{P}$ dispersion flight 
Acknowledgments We want to deeply thank Milagros de Vallejo, Juan Blanco and the technical staff at the "Dirección General de Montes y Conservación de la Naturaleza (Government of Cantabria)" for their invaluable help in the field work. We thank Silvia Gonzalez, from the National Research Center on Human Evolution (Burgos, Spain), for her work in the SEM pictures. Silvia Bezos is also acknowledged for her accurate work in the cycle drawing. Fernando M. Alves-Santos is thankful for the help with the insect identification. Sarah Kathryn Fox, Nathan Brenville and Christine Francis are acknowledged for the manuscript revisions.

Funding This research was financially supported by the Spanish Ministry of the Environment and Rural and Marine Affairs project "Etiology, Epidemiology and Control of Fusarium circinatum" and by Cantabria Government project "Control of pitch canker of pines in Cantabria region".

\section{References}

Ambourn AK, Juzwik J, Eggers JE (2006) Flight periodicities, phoresy rates, and levels of Pseudopityophthorus minutissimus branch colonization in oak wilt centers. For Sci 52:243-250

Bezos D, Martínez-Álvarez P, Diez JJ, Fernandez M (2013) Bark beetles and fungi associated to pitch canker disease caused by Fusarium circinatum. Valsaín, Segovia (Spain)

Bouhot L, Lieutier F, Debouzie D (1988) Spatial and temporal distribution of attacks by Tomicus piniperda L. and Ips sexdentatus Boern. (Col., Scolytidae) on Pinus sylvestris. J Appl Entomol 106:356-371

Dwinell LD, Barrows-Braddus J, Kuhlman EG (1985) Pitch canker: a disease complex of southern pines. Plant Dis 69:270-276

Faccoli M (2006) Morphological separation of Tomicus piniperda and T. destruens (Coleoptera: Curculionidae: Scolytinae): new and old characters. Eur. J Entomol 103:433

Fernández M, Alonso J, Costas J (1999) Shoot feeding and overwintering in the lesser pine shoot beetle Tomicus minor (Col., Scolytidae) in north-west Spain. J Appl Entomol 123:321-327

Gallego D, Galian J (2001) The internal transcribed spacers (ITS1 and ITS2) of the rDNA differentiates the bark beetle forest pests Tomicus destruens and T. piniperda. Insect Mol Biol 10:415-420. doi:10. 1046/j.0962-1075.2001.00279.x

Gallego D, Canovas F, Esteve M, Galián J (2004) Descriptive biogeography of Tomicus (Coleoptera: Scolytidae) species in Spain. J Biogeogr 31:2011-2024

Gallego D, Galián J, Diez J, Pajares J (2008) Kairomonal responses of Tomicus destruens (Col., Scolytidae) to host volatiles $\alpha$-pinene and ethanol. J Appl Entomol 132:654-662

Jacobs K, Bergdahl DR, Wingfield MJ, Halik S, Seifert KA, Bright DE, Wingfield BD (2004) Leptographium wingfieldii introduced into North America and found associated with exotic Tomicus piniperda and native bark beetles. Mycol Res 108:411-418

Jankowiak R, Bilański P (2007) Fungal flora associated with Tomicus piniperda L. in an area close to a timber yard in southern Poland. J Appl Entomol 131:579-584

Kirisits T (2004) Fungal associates of European bark beetles with special emphasis on the ophiostomatoid fungi. In: Lieutier F, Day KR, Battisti A, Grégoire J, Evans HF (eds) Bark and wood boring insects in living trees in Europe, a synthesis. Springer, New York, pp $181-236$

Kirkendall LR, Faccoli M, Ye H (2008) Description of the Yunnan shoot borer, Tomicus yunnanensis Kirkendall \& Faccoli sp. n. (Curculionidae, Scolytinae), an unusually aggressive pine shoot beetle from southern China, with a key to the species of Tomicus. Zootaxa 1819:25-39
Landeras E, García P, Fernández Y, Braña M, Fernández-Alonso O, Mendez-Lodos S, Pérez-Sierra A, León M, Abad-Campos P, Berbegal M (2005) Outbreak of pitch canker caused by Fusarium circinatum on Pinus spp. in northern Spain. Plant Dis 89:1015

Långström B (1980) Distribution of pine shoot beetle attacks within the crown of Scots pine. Stud For Suec 154:1-24

Långström B (1982) Life cycles and shoot-feeding of the pine shoot beetles. Stud For Sue, Uppsala

Laucirica JM, Muguruza JR (1997) Presencia de Fusarium subglutinans sp. pini en viveros de pino radiata en Bizkaia. Actas XIV Reunión anual del Grupo de Trabajo Fitosanitario de Forestales Parques y Jardines Zaragoza, pp. 301-303.

Leach LG (1940) Insects transmission of plant diseases. McGraw Hill, New York

Leslie JF, Summerell BA (2006) The Fusarium laboratory manual. Blackwell Publishing, Iowa

Lieutier F, Yart A, Garcia J, Ham MC, Morelet M and Levieux J (1989) Champignons phytopathogčnes associés ā deux coléoptčres scolytidae du pin sylvestre (Pinus sylvestris L.) et étude préliminaire de leur agressivité envers l'hôte.

Lieutier F, Yart A, Salle A (2009) Stimulation of tree defenses by Ophiostomatoid fungi can explain attack success of bark beetles on conifers. Ann For Sci 66:801p1-801p22

Lieutier F, Långström B, Faccoli M (2015) The genus Tomicus. In: Vega FE, Hofstetter RW (eds) Bark beetles: biology and ecology of native and invasive species. Academic, London, pp 371-426

López S, Romón P, Iturrondobeitia JC, Goldaracena A (2007) Los escolítidos de las coníferas del País Vasco: guía práctica para su identificación y control. Eusko Jauriaritzaren Argitalpen Zerbitzu Nagusia $=$ Servicio Central de Publicaciones del Gobierno Vasco

Martín A, Etxebeste I, Pérez G, Álvarez G, Sánchez E, Pajares J (2013) Modified pheromone traps help reduce bycatch of bark-beetle natural enemies. Agric For Entomol 15:86-97

Martínez-Álvarez P, Alves-Santos FM, Diez JJ (2012) In vitro and in vivo interactions between Trichoderma viride and Fusarium circinatum. Silva Fenn 46:303-316

Martínez-Álvarez P, Pando V, Diez J (2014) Alternative species to replace Monterey pine plantations affected by pitch canker caused by Fusarium circinatum in northern Spain. Plant Pathol 63:1086-1094

McCullough DG, Smitley DR (1995) Evaluation of insecticides to reduce maturation feeding by Tomicus piniperda (Coleoptera: Scolytidae) in Scotch pine. J Econ Entomol 88:693-699

McNee WR, Wood DL, Storer AJ, Gordon TR (2002) Incidence of the pitch canker pathogen and associated insects in intact and chipped Monterey pine branches. Can Entomol 134:47-58

Morales-Ramos JA, Rojas MG, Sittertz-Bhatkar H, Saldaña G (2000) Symbiotic relationship between Hypothenemus hampei (Coleoptera: Scolytidae) and Fusarium solani (Moniliales: Tuberculariaceae). Ann Entomol Soc Am 93:541-547

Nirenberg HI, O’Donnell K (1998) New Fusarium species and combinations within the Gibberella fujikuroi species complex. Mycologia 90:434-458

Paine T, Raffa K, Harrington T (1997) Interactions among scolytid bark beetles, their associated fungi, and live host conifers. Annu Rev Entomol 42:179-206

Romón P, Iturrondobeitia JC, Gibson K, Lindgren BS, Goldarazena A (2007a) Quantitative association of bark beetles with pitch canker fungus and effects of verbenone on their semiochemical communication in Monterey pine forests in northern Spain. Environ Entomol 36:743-750

Romón P, Zhou XD, Iturrondobeitia JC, Wingfield MJ, Goldarazena A (2007b) Ophiostoma species (Ascomycetes: Ophiostomatales) associated with bark beetles (Coleoptera: Scolytinae) colonizing Pinus radiata in northern Spain. Can J Microbiol 53:756-767 
Romón P, Troya M, de Gamarra MEF, Eguzkitza A, Iturrondobeitia J, Goldarazena A (2008) Fungal communities associated with pitch canker disease of Pinus radiata caused by Fusarium circinatum in northern Spain: association with insects and pathogen-saprophyte antagonistic interactions. Can J Plant Pathol 30:241-253

Russo G (1946) Pine bark-beetles of the Tuscan coast. Boll Ist Entomol Univ Bologna 15:297-314

Six DL, Wingfield MJ (2011) The role of phytopathogenicity in bark beetle-fungus symbioses: a challenge to the classic paradigm. Annu Rev Entomol 56:255-272

Solheim H, Krokene P, Långström B (2001) Effects of growth and virulence of associated blue-stain fungi on host colonization behaviour of the pine shoot beetles Tomicus minor and T. piniperda. Plant Pathol 50:111-116
Storer AJ, Wood DL, Gordon TR (2004) Twig beetles, Pityophthorus spp. (Coleoptera: Scolytidae), as vectors of the pitch canker pathogen in California. Can Entomol 136:685-693

Tiberi R, Fagge M, Panzavoha T, Peverrieri S (2009) Feeding preference of Tomicus destruens progeny adults on shoots of five pine species. Bull Insectol 62:261-266

Viljoen A, Wingfield M, Kemp G, Marasas W (1995) Susceptibility of pines in South Africa to the pitch canker fungus Fusarium subglutinans f. sp. pini. Plant Pathol 44:877-882

Webber J (2008) Experimental studies on factors influencing the transmission of Dutch elm disease. For Sys 13:197-205

Whitehill JG, Lehman JS, Bonello P (2007) Ips pini (Curculionidae: Scolytinae) is a vector of the fungal pathogen, Sphaeropsis sapinea (Coelomycetes), to Austrian pines, Pinus nigra (Pinaceae). Environ Entomol 36:114-120 